\title{
Communicative Names of Cities and Streets
}

\author{
Cosimo Palagiano \\ Sapienza University of Rome, Italy
}

\begin{abstract}
This paper presents the different categories of communicative names of cities and streets with some examples all over the world. The commemorative role is playing also by the names of some continents, like America, from the Amerigo Vespucci's name. But many countries and states particularly in the Americas remember the Columbus' name. Many city names remember political leaders of great significance, like Washington after Georg Washington, Monrovia after James Monroe, Leningrad (today Saint Petersburg, which remembered the tsar Peter I). Two soviet leaders, Lenin and Stalin were remembered by two Russian cities, Leningrad and Stalingrad, nowadays Saint Petersburg and Volgograd. The name Ho Chi Minh, after the North Vietnamese leader. The names of other regions and cities have been considered, like many cities and islands named Georgia after some kings. Also Louisiana, The Carolinas, Léopoldville, Elisabethville were named after other kings and queens. Some cities and islands' names remember explorers, like Cook, Stanley, Lourenço Marques (today Maputo, after the name of a river), Brazzaville after, Pietro Paolo Savorgnan di Brazzà etc. Rio de Janeiro is named after the date of its discovery. Many place names were named after Alexander the Great, outer than the Italian Alesssandria, named after the Pope Alexander III. Many place names remember Saints, particularly in Latin America, but also in North America, like St. Francisco. The streets' names are many all over the world. In Rome we have streets names to politicians, like Camill Benso di Cavour, Giuseppe Mazzini and Palmiro Togliatti; writers like Alessandro Manzoni and Torquato Tasso. A name like Giuseppe Garibaldi is extremely diffused in all Italy and also in other countries.
\end{abstract}

Key words: Continents' names, cities' and islands' names, streets' names, explorers' names, saints' manes, kings' and queens' names, politicians' names.

\section{Introduction}

The aim of this paper is to present the different categories of communicative names of cities and streets with some examples all over the world. A major function of the communication is the commemoration. But also the names of some continents and countries play a commemorative function. For instance the name of the new continent America appears perhaps for the first time on the Martin Waldseemüller' world map of 1507, entitled Universalis cosmographia secundumPtholomaei traditionem et AmericiVespucii aliorumque lustrationes. Waldseemüller used the name of Americus Vespucii like a base for the new name, taking the feminine form America, according to the names of other continents: Europa, Asia, Africa, Australia and Oceania. On the JagellonianGlobe of 1511 the inscription "America noviter reperta" appears

Corresponding author: Cosimo Palagiano, Emeritus Professor, research fields: geography, cartography. for the first time on a continent America not linked with Asia.

For the communicative names of countries we can mention Columbia. The name "Colombia" is derived from the last name of Christopher Columbus (Italian: Cristoforo Colombo, Spanish Cristóbal Colón). It was conceived by the Venezuelan revolutionary Francisco de Miranda like a reference to all the New World, but especially to those under the Spanish and Portuguese rule. The name was later adopted by the Republic of Colombia of 1819, formed out of the territories of the old Viceroyalty of New Granada (modern-day Colombia, Panama, Venezuela, Ecuador, and northwest Brazil). Many states, cities and streets refer to the same sailor Columbus:

District of Columbia, the federal district in which the capital of the United States is located; Columbia, Alabama, a city; Columbia, California, a census-designated place and former boomtown; Columbia, San Diego, California, a neighborhood; 
Columbia, Connecticut, a city; Columbia, Illinois, a city; Columbia Fayette County, Indiana, an unincorporated city; Columbia, Kentucky, a city; Columbia, Louisiana, a city; Columbia, Maine, a city; Columbia, Mississippi, a city; Columbia, Missouri, a city; Columbia, Missouri Metropolitan Area; Columbia, New Hampshire, a city; Columbia, New York, a city; Columbia, North Carolina, a city; Columbia, Pennsylvania, a borough; Columbia, South Carolina, the capital of South Carolina; Columbia, South Carolina Metropolitan Area; Columbia, South Dakota, a city; Columbia, Tennessee, a city; Columbia, Virginia, a city; Columbia, West Virginia, an unincorporated community in Fayette Country; Columbia, former name of West Columbia, Texas, a city; Columbia (electoral district), a former provincial electoral district in British Columbia, Canada, 1903-1928; Columbia Island (New York); Columbia Island (District of Columbia); Columbia Street, New Westminster, the main downtown street of that city, in British Columbia, Canada.

\section{Names of Political Leaders of Great Significance}

Many city names remember political leaders of great significance:

We can name, e.g., Georg Washington (February $22^{\text {nd }}, 1732$-December $\left.14^{\text {st }}, 1799\right)$, who was the first President of the United States (1789-1797), the Commander-in-Chief of the Continental Army during the American Revolutionary War, and one of the Founding Fathers of the United States. He presided over the convention that drafted the United States Constitution, which replaced the Articles of Confederation and remains the supreme law of the land.

His name is remembered both by the current capital of the United States and a state of the United States.

Two soviet leaders, Lenin and Stalin were remembered by two Russian cities: Leningrad and Stalingrad. In 1914 the name of Leningrad was changed from Saint Petersburg to Petrograd, in 1924 to Leningrad, and in 1991, back to Saint Petersburg. Vladimir Ilyich Lenin; born Vladimir Ilyich Ulyanov (22 April, 1870-21 January, 1924) was a Russian communist revolutionary, politician and political theorist. Under his administration, the Russian Empire disintegrated and was replaced by the Soviet Union. Saint Petersburg was founded by Tzar Peter the Great on May 27, 1703. Between 1713-1728 and 1732-1918, Saint Petersburg was the imperial capital of Russia.

There is another St. Petersburg: a city in Pinellas County Florida, United States. It was named after Saint Petersburg, Russia, where Peter Demens, one of its founders with John Williams, had spent half of his youth.

To Iosif Vissarionovič Džugašvili (1878-1953) known like Joseph Stalin is due one of the names of Volgograd, formerly Tsaritsyn 1589-1925, and Stalingrad (1925-1961).

Lenin and Stalin, like George Washington, were also military commandants.

Togliatti was founded in 1737 like a fortress called Stavropol (Ста́врополь) by the Russian statesman Vasily Tatishchev. Informally it was often referred like Stavropol-on-Volga

(Ста́врополь-на-Во́лге, Stavropol-na-Volge) to distinguish from Stavropol, a large city in southwest Russia.

The construction of the Kuybishev Dam and Hydroelectric Station on the Volga River in the 1950s created the Kuybishev Reservoir, which covered the existing location of the city, and it was completely rebuilt on a new site. In 1964, the city was renamed Толья́тти (Tolyatti, after Palmiro Togliatti, the longest-serving secretary of the Italian Communist Party).

The name of Giuseppe Garibaldi (1807-1882), known also like the hero of two worlds, is remembered in a town in Rio Grande do Soul, southern Brazil. It was settled by Italian immigrants, predominantly Venetians in the late $19^{\text {th }}$ century. 
The name of Garibaldi is remembered also in Plaza Garibaldi which is located in historic downtown Mexico City, on Eje central (Lázaro Cárdenas) between historic CalleRepública de Honduras and CalleRepública de Peru, a few blocks north of the Palacio de BellasArtes.

An Italian Club Garibaldi was established in 1882 in Wellington by the first inhabitants of the region.

Of course, most Italian cities have streets and squares named after Garibaldi.

Louisiana was named after Louis $14^{\text {th }}$, King of France from 1643 to 1715 . When René Robert Cavelier, Sieur de la Salle claimed the territory drained by the Misissippi River for France, he named it La Louisiane, meaning "Land of Louis".Once part of the French Colonial Empire, the Louisiana Territory stretched from present-day Mobile Bay to just north of the present-day Canadian border, and included a small part of what is now southwestern Canada.

There are two cities named Vladimir: Volodymyr-Volyskyr in Ukraine and Vladimir in Russia named after Valdimir Monomakh.

\subsection{Monrovia}

James Monroe (Monroe Hall, April 28, 1758 - New York, July 4, 1831) was an American politician. It was the $5^{\text {th }}$ (1817-1825) President of the United States. He is credited with the development of the Monroe Doctrine, which focused its ideology in the phrase "America for the Americans". This doctrine will be taken up by Theodore Roosevelt regarding the famous Roosevelt Corollary. Monrovia, capital of Liberia, founded in 1822 during his presidency, was named after him.

Monrovia is another city located in the foothills of the San Gabriel Mountains in the San Gabriel Valley of Los Angeles County, United States

\subsection{Georgia}

The name Georgia of many states, cities and islands along all the world is eponymous for the first four
British Monarchs of the House of Hannover: George I and George II of the Great Britain, George III and George IV, of the United Kingdom who reigned in continuous succession from August 1714 to June 1830. In honor of these monarchs the Georgian architecture was born in most English speaking between 1720 and 1820. The style was revived in the late $19^{\text {th }}$ century in the United States like Colonial Revival Architecture, and in the early $20^{\text {th }}$ century in the Great Britain, referred to the Neo-Georgian architecture.

Many other cities are named Georgetown, but this name derives from different kings, politicians etc.

The name of the British Colony in North America derives from George II of Great Britain: This colony was founded by James Edward Oglethorpe in 1732.

There is another state named Georgia in Caucasus, but its derivation is not from a king: the endonym of this country is Sakartvelo. The inhabitants Kartelebi speak the kartuli language. The esonym Georgia derives from the Persian Gurji that in turn derives from the Arabian جورجيا. This esonym was affected from the Greek $\gamma \varepsilon 0 \rho \gamma$-, that refers to agriculture.

\subsection{Louisiana, The Carolinas}

The US state of Louisiana was named after Louis XIV, King of France from 1643 to 1715.

The Carolinas (North and South) were explored by Giovanni da Verrazzano in 1524 and then was colonized by Walter Raleigh, from which he took the name of the capital city. Became a British colony (the Province of Carolina), was so named by King Charles II of England in memory and honor of his father Charles I, beheaded January 30, 1649 at the end of the English Civil War. The division between North and South Carolina became complete in 1712 .

\subsection{Leopoldville, Elisabethville, Stanleyville, Brazzaville, Kinshasa}

The two Republics of Congo show a splendid example of a naming after the changes of power and after explorers. 
The explorer Henry Morton Stanley 1881 Leopoldville in honor of the king Leopold II. In 1966 the name was changed in Kinshasa, after the name of a village close to the city.

Henry Morton Stanley also founded Stanley Falls Station in 1883, after Stanleyville. Now Stanleyville is named Kisangani.

In 880 the explorer Pietro Savorgnan de Brazzà had founded Brazzaville.

Elisabethville was founded by Belgian colonizers in 1910 in honor of the Queen Elisabeth, wife of the King Albert I. Elisabetville is now named Lumumbashi after the politician Patrice Lumumba assassinated in 1961.

\subsection{Ho Chi Minh}

Ho Chi Minh City has gone by several different names during its history, reflecting settlement by different ethnic, cultural and political groups. In the 1860 s the occupying force adopted the name Saigon for the city, a westernized form of the traditional name.

The name commemorates Ho Chi Min, the pre-eminent North Vietnamese leader. This name, though not his given name, was one he favored throughout his later years. The name means "bringer of light". Ho Chi Minh was a Communist revolutionary who led the Việt Minh independence movement which established the communist-ruled Democratic Republic of Vietnam in 1945. He was the prime minister from 1945 to 1955 and the president of the Democratic Republic of Vietnam from 1945 to 1969.

\subsection{Rio de Janeiro}

The most known example of a city named after the date of its discovery is Rio de Janeiro.

Europeans first encountered Guanabara Bay on January $1^{\text {st }}, 1502$ (hence Rio de Janeiro, "January River"), by a Portuguese expedition under explorer Gaspar de Lemos captain of a ship in Pedro Álvares Cabral's fleet, or under Gonçalo Coelho. Allegedly the Florentine explorer Amerigo Vespucci participated like observer at the invitation of King Manuel I in the same expedition. The region of Rio was inhabited by the Tupi, Puri, Botocudo and Maxacalí peoples.

Since initially Europeans believed that the Guanabara Bay was the mouth of a river, they called in fact "Rio de Janeiro" (or "River of January" in Portuguese). The Tupi Indians who inhabited the Guanabara Bay called newcomers carioca (kara 'iwa = white man and oka = house, where the house of the carioca $=$ white).

\section{Explorers}

After Columbus and Vespucci the most known explorer is of course James Cook.

The Cook Islands were first settled in the $6^{\text {th }}$ century CE by Polynesian people who migrated from Tahiti, an island $1154 \mathrm{~km}$ to the north of Cook Islands.

Spanish ships visited the islands in the $16^{\text {th }}$ century; the first written record of contact with the islands came with the sighting of Pukapuka by Spanish sailor Álvaro de Mendaña de Neira in 1595 who called it San Bernardo (Saint Bernard). Pedro Fernandes de Queirós, a Portuguese captain working for the Spanish crown, made the first recorded European landing in the islands when he set foot on Rakahanga in 1606, calling it Gente Hermosa (Beautiful People).

British navigator Captain James Cook arrived in 1773 and 1777 and named the islands the Hervey Islands; the name "Cook Islands", in honor of Cook, appeared on a Russian naval chart published in the 1820 s.

\subsection{Lourenço Marques}

On the northern bank of Espírito Santo Estuary of Delagoa Bay, an inlet of the Indian Ocean, Lourenço Marques was named after the Portuguese navigator who, with António Caldeira, was sent in 1544 by the governor of Mozambique on a voyage of exploration. They explored the lower courses of the rivers emptying their waters into Delagoa Bay, notably the Espírito Santo. The forts and trading stations that the Portuguese established, abandoned and reoccupied on 
the north bank of the river, were all called Lourenço Marques. The existing town dates from about 1850, the previous settlement having been entirely destroyed by the natives. The town developed around a Portuguese fortress completed in 1787.

The Peple's Republic of Mozambique was proclaimed on 25 June 1975 in accordance with the Lusaka accord signed in September 1974. A parade and a state banquet completed the independence festivities in the capital, which was expected to be renamed Can Phumo, or "Place of Phumo", after a Shangaan chief who lived in the area before the Portuguese navigator Lourenço Marques first visited the site in 1545 and gave his name to it.

However, after independence, the city's name was changed (in February 1976) to Maputo. Maputo's name reputedly has its origin in the Maputo River.

Most of the streets of the city, originally named with the names of the Portuguese heroes or important dates in Portuguese history, had their names changed in African languages, revolutionary figures, or pre-colonial historical names.

\subsection{Tasmania}

The state is named after Dutch explorer Abel Tasman, who made the first reported European sighting of the island on 24 November 1642. Tasman named the island "Anthony van Diemen's Land" after his sponsor Anthony van Die, the Governor of the Dutch East Indies. The name was later shortened to Van Diemen's Land by the British. It was officially renamed Tasmania in honor of its first European discoverer on $1^{\text {st } J a n u a r y ~} 1856$.

Abel Janszoon Tasman (1603-1659) was a Dutch seafarer, explorer and merchant, best known for his voyages of 1642 and 1644 in the service of the VOC (Vereenigde Geoctroyeerde Oostindische Compagnie) (United East Company). He was the first known European explorer to reach the islands of Van Diemen's Land (now Tasmania) and New Zealand, and to sight the Fiji islands. His navigator François
Visscher, and his merchant Isaak Gilsemans, mapped substantial portions of Australia, New Zealand and some Pacific Islands.

\subsection{Alexandria and Alessandria}

Alexandria (اسكندرية) is a city in Egypt. There are many cities named Alexandria in the Old and New World, which refer to Alexander the Great, except any of them. I offer a complete list of them:

Places founded or renamed Alexandria by Alexander the GreatAlexandria Aracosia, Afghanistan; now called Kandahar (a contraction of Iskandahar); Alexandria Ariana, Afghanistan; Alexandria Bucephalous, Pakistan, on the Jhelum; Alexandria in Orietai, Balochistan, Pakistan; Alexandria Carmania, unknown site in Kerman Province, Iran; Alexandria Eschate, "the Farthest", Tajikistan; Ghazni, formerly Alexandria in Opiania; Alexandria on Caucasus, Afghanistan; Alexandria on the Indus, Pakistan; Alexandria on the Oxus, Afghanistan; Alexandria Susiana, Iran; Alexandria Troas, Turkey;Alinda (Alexandria on the Latmos), Turkey; Cebrene (formerly Alexandria), Turkey; Iskandarya Alexandria), Iraq; İskendurun (Alexandria near Issos), Turkey; Merv, Turkmenistan, sometimes also called Alexandria Margiana.

3.3.1 Other Places Named Alexandria

Australia: Alexandria, Northern Territory; Alexandria, New South Wales; Alexandria, Victoria; Alexandria Station

Canada: Alexandria, British Columbia; Alexandria, Ontario

Ukraine: Oleksandriia, Kirovohrad, a city in central Ukraine; OlexandriaRivne Oblast, a village in northwestern Ukraine

United States: Alexandria, Alabama; Alexandria, California; Alexandria, Indiana; Alexandria Kentucky; Alexandria, Louisiana; Alexandria, Louisina Metropolitan area, a metropolitan area in central Louisiana; Alexandria, Missouri; Alexandria, Minnesota; Alexandria Nebraska; Alexandria, New 
Hampshire; Alexandria, New York; Alexandria Bay, New York; Alexandria Ohio; Alexandria, Pennsylvania; Alexandria, South Dakota; Alexandria, Tennessee; Alexandria, Virginia; Alexandria County, formerly in the District of Columbia and later in Virginia; Alexandria Township, Douglas County; Alexandria Township, New Jersey; West Alexandria, Ohio.

Other countries: Aleksandronopol, Armenia; Alexandria, Brazil; Alexandreia, Greece Alexandrium, ancient site in Israel; Alessandria del Carretto, Italy; Alessandria, Italy; Alessandria dellaRocca; Alexandria, Giamaica; Alexandria, Romania; Alexandria, West Dunbartonshire, Scotland; Alexandria Eastern Cape, South Africa.

3.3.2 Some cities named Alexandria, that do not refer to Alexander the Great

\section{Alessandria del Carretto, Italy.}

Its official foundation, commissioned by the Marchese Alessandro Pinion lord of the Wheelbarrow, dates back to the $7^{\text {th }}$ century by farmers from the nearby Orion. Subsequently, the population increased in number, thanks to people from neighboring towns like Albidona, Cerchiara and San Lorenzo Bellizzi.

\section{Alessandria della Rocca}

Alessandria della Rocca was the name given to the country by royal decree of November 7, 1862: Previously, in fact, the City had other names. The first was Alessandria della Pietra, due to the ancient name of the estate owner, Alessandro Presti, and close to Castello della Pietra D'Amico, dating back to the Saracen. In 1713, appointed Victor Amadeus II, King of Sicily, the municipalities were established: the town took the name of Agrigento in Sicily Alexandria, to be distinguished from common homonyms in the various states of Italy. Finally, in 1862, assumed the name that still holds: Alessandria della Rocca, in honor of Our Lady of the Rock, the patron saint of the country.

\section{Alessandria, Piedmont, Italy}

The city was born in the second half of the $12^{\text {th }}$ century with the name of Civitas Nova on an existing urban core consists of the ancient town of Rovereto.
The city was officially founded in 1168 and in that year took its current name in honor of Pope Alexander III, who promulgated at the time the action against the Holy Roman Empire and had excommunicated Frederick Barbarossa.

\section{Alexandria, Romania}

The city was officially founded in 1834 , on the initiative of some residents of the nearby town of Mavrodin and Zimnicea and took the name of Alexandria in honor of the Prince of Romania Alexandru Dimitrie Ghica (ruled 1834-1842), whose imposing cenotaph is housed in the Cathedral of St. Alexander, at the center of the city. The urban structure of the city was designed by Otto von Moritz, already known to be true at the time supervised the renovation of Giurgiu and Brăila, which imposed a number of long straight roads and perpendicular to each other, with the main axis parallel to the river Vedea

\section{The Devotion to the Virgin Mary}

\subsection{Buenos Aires}

When the Aragonese conquered Caglairi, Sardinia from the Pisans in 1324, they established their headquarters on top of a hill that overlooked the city. The hill was known to them like BuenAyre (or "Bonaria" Local linguage), like it was free of the foul smell prevalent in the old city (the cattle area), which is adjacent to swampland. During the siege of Cagliari, the Aragonese built a sanctuary to the Virgin Mary on top of the hill. In 1335, King Alfonso the Gentle donated the church to the Mercedarians, who built an abbey that stands to this day. In the years after that, a story circulated, claiming that a statue of the Virgin Mary was retrieved from the sea after it miraculously helped to calm a storm in the Mediterranean Sea. The statue was placed in the abbey. Spanish sailors, especially Andalusians, venerated this image and frequently invoked the "Fair Winds" to aid them in their navigation and prevent shipwrecks. A sanctuary to the Virgin of Buen Ayre would be later erected in Seville. 
In the first foundation of Buenos Aires, Pedro de Menoza called the city "Holy Mary of the Fair Winds", a name chosen by the chaplain of Mendoza's expedition, a devotee of the Virgin of BuenAyre. Mendoza's settlement soon came under attack by indigenous people, and was abandoned in 1541.

For many years, the name was attributed to Sancho del Campo, who is said to have exclaimed: How fair are the winds of this land!, like he arrived. But Eduardo Madero, in 1882, after conducting extensive research in Spanish archives would ultimately conclude that the name was closely linked with the devotion of the sailors to Our Lady of Buen Ayre.

\subsection{Los Angeles}

The Los Angeles coastal area was first settled by the Tongva (or Gabrieleños) and Chumash Native American tribes thousands of years ago. A Gabrielino settlement in the area was called iyáangà (written Yang-na by the Spanish), meaning "poison oak place". Juan Rodríguez Cabrilo, a Portuguese-born explorer, claimed the area of southern California for the Spanish Empire in 1542. Gaspar de Portolà and Franciscan missionary Juan Crespí, reached the present site of Los Angeles on August 2, 1769. In 1771, Franciscan friar Junípero Serra directed the building of the Mission San Gabriel Arcángel, the first mission in the area. On September 4, 1781, a group of forty-four settlers known as "Los Pobladores" founded the pueblo called "El Pueblo de Nuestra Señora la Reina de los Ángeles del Río de Porciúncula"; in English it is "The Town of Our Lady the Queen of Angels of the Porciúncula River". The Queen of Angels is an honorific of the Virgin Mary. Two-thirds of the settlers were mestizo or mulatto with a mixture of African, indigenous and European ancestry. The settlement remained a small ranch town for decades, but by 1820 , the population had increased to about 650 residents. Today, the pueblo is commemorated in the historic district of Los Angeles Pueblo Plaza and Olvera Street, the oldest part of Los Angeles.

\section{The Commemoration of Battles}

After the reclamation of the PontinePlainmanyvillages were founded to commemorate some of the battles of the First World War: Borgo Sabotino, Borgo Carso, Borgo Vodice, Borgo Grappa, Borgo Piave, Borgo Hermada, Borgo Montello, Borgo Bainsizza, Borgo Pasubio, Borgo Podgora, Borgo Faiti, Borgo Isonzo, Borgo. San Michele, Borgo Montenero.

In the city of Rome, a Square is named Piazza dei Caduti del 19 luglio 1943.

On July 19, 1943, during the Second World War, this place was struck by the Allied bombing of Rome, with the aim of attacking the freight still active today, along with the district Tiburtinus to Prenestino at Casilino to Labicano and Tuscolano. Six days later, the Grand Council of Fascism removed the confidence to Mussolini and Fascism ended. At 11:03, 662 U.S. bombers reeled bombs 4000 (about 1060 tons) on the district, resulting in about 3000 deaths, of which 1377 identified and 11000 injured.

In Rome other battles are remembered: Piazza dei Cinquecento commemorates the 500 Italian soldiers massacred in Dogali (Abyssinia) in 1887; Via dell'Amba Aradam recalls the battle of 1936 in Abyssinia; Piazza delle Cinque Giornate remembers the five days of 1848, when the Milanese rose up against the Austrian soldiers.

\section{Business Cities}

Some cities' names have a commercial meaning, as: San Marzano sul Sannio

The San Marzano tomato of the Agro Nocerino-Sarnese is a variety of tomato recognized as a fruit or vegetable in Italian Protected Designation of Origin.

\subsection{San Pellegrino}

At the end of the $18^{\text {th }}$ century San Pellegrino is developed as a Joint-Stock Company town, thanks to the sulphate-alkaline-earthy waters that flow at a 
constant temperature of 26 degrees, known since the Middle Ages. In the $20^{\text {th }}$ century the town is transformed into an elegant Spa. Is created, the Joint-Stock Company (now belonging to the San Pellegrino Joint-Stock Company, known industry that produces water and carbonated soft drinks which belongs to the Swiss Nestlé). The fame of the town increases with the construction of the Municipal Casino in 1904 and the Grand Hotel in 1905.

\subsection{Fiuggi}

Fiuggi, originally called Anticoli di Campagna, gained fame as early as the $14^{\text {th }}$ century, when Pope Boniface VIII claimed his kidney stones had been healed by the mineral waters from the nearby Fiuggi spring. Two centuries later Michelangelo also extolled the virtues of the water that cured him of what he called "the only kind of stone I couldn't love". Soon Acqua di Finggi was being sent in bottles to all of Europe's royalty. Not until the turn of the $20^{\text {th }}$ century did it become fashionable to make pilgrimages to spa towns (bathing-places) and it was around this time that the King of Italy renamed Anticoli in honor of its most celebrated attraction - The Fiuggi Water.

\subsection{Evian}

Evian is a brand of luxury mineral water coming from several sources near Évian-les-Bains, on the south shore of Lake Geneva.

Today, Evian is owned by Danone Group, a French multinational company. In addition to the mineral water, Danone Group uses the Evian name for a line of organic skin care products as well as a luxury resort in France

In popular culture, Evian is portrayed as a luxury and expensive bottled water. It was named in Agatha Christie's Murder on the Orient Express.

\subsection{Dalmine}

The town of Dalmine lies $8 \mathrm{~km}$ south-west of Bergamo, on the east bank of the river Brembo. The
Hon Count Walter Danieli in 1907 persuaded the German steel industry to settle Mannesmann in Dalmine. In 1920 the company became Italian during the first world war, he changed his name to "Dalmine Joint-Stock Company", taking its name from the area in which it was placed. In 1927 it was the deliberate creation of new and unique town of Dalmine (Royal Decree of July 7, 1927). With the economic crisis of the thirties the property of "Dalmine" became public, with the passage of the shares of the company to Finsider (Financial steel IRI).

\section{The Veneration of Saints}

\subsection{San Francisco}

The city was founded by the Spanish in 1776 under the name of La Misión de Nuestro Padre San Francisco de Asís (Mission of Our Father Saint Francis of Assisi). Following independence from Spain, the area became part of Mexico. In 1835 the Englishman William Richardson led a first significant urban expansion outside of the immediate vicinity of the Mission: thus it was that the city, then called Yerba Buena, began to attract a significant immigration of American settlers.

\subsection{Santa Barbara}

The city was founded by the Spanish explorer Sebastian Vizcaino who, during his voyage of exploration of the Pacific coast, landed here on the day of St. Barbara in 1602, dedicating the site. However, urban development began only in the $19^{\text {th }}$ century. In 1850 the city was annexed to the United States.

\subsection{Santa Catarina}

Santa Catarina is a state in Southern Brazil. Its capital is Florianópolis, which mostly lies on the Santa Catarina Island. Neighbouring states are Rio Grande do Sul to the south and Paraná to the north. It is bounded on the east by the Atlantic Ocean, and to the west it borders the province of Misiones, Argentina. Most of its inhabitants are descendants of Portuguese, Danish, Dutch, German, Italian and Norwegian immigrants. 


\subsection{Saint Lucia}

Saint Lucia is a sovereign island country in the eastern Caribbean Sea on the boundary with the Atlantic Ocean. Part of the Lesser Antilles, it is located north/northeast of the island of Saint Vincent, northwest of Barbados and south of Martinique. Its capital is Castries.

\subsection{Saint Elena}

Saint Helena, named after Saint Helena of Costantinople, is a tropical island of volcanic origin in the South Atlantic Ocean. It is part of the British Overseas Territory of St. Helena, Ascension, and Tristan da Cunha, which also includes Ascension Island and the islands of Tristan da Cunha.

\subsection{Saint Louis}

The city of St. Louis was founded in 1764 by Pièrre Laclede and Auguste Chouteau, and named for Louis $9^{\text {th }}$ of France, canonized by Bonifacius $8^{\text {th }}$ in 1297 .

San Diego, California was named after the flagship of Sebastián Vizcaino.

Many cities are named Santiago, particularly in Latin America.

\section{The Commemorative Street Names}

Most of the commemorative cities names is connected with a variety of derivations: from the names of poets, like Victor Hugo in Paris, politicians, like Palmiro Togliatti in Rome, Marquês de Pombal ${ }^{1}$ in Lisbon and Eisenhower in New York, philosophers, like Voltaire (François-Marie Arouet) in Paris, and Immanuel Kant in Rome, musicians, like Wolfgang Amadeus Mozart, in Vienna and Rome, explorers like Cristoforo Colombo in Rome, chemists and physicians, like François-Vincent Raspail in Paris and Pierre and Marie Curie in Rome, actors like Alberto Sordi and Anna Magnani in Rome, popes like Leone XIII, Pio XI

\footnotetext{
1 Sebastião José de Carvalho e Mello, marquês de Pombal, also called (1759-1769) conde de Oeiras (1699, 1782), Portuguese reformer and virtual ruler of his country from 1750 to 1777 .
}

and Anastasio II in Rome, kings like Carlo III di Borbone (Charles of Bourbon (1716-1788), King of Spain, Naples, and Sicily) in Caserta, Vittorio Emanuele II, in Rome, battles, like Lepanto in Rome, writers like Alessandro Manzoni in Rome, miniaturists like Oderisi da Gubbio (1240?-1299), in Rome, scientists like Guglielmo Marconi, in Rome.

Of course Viale Giulio Cesare could not miss in Rome, as well as references to Augustus, who gave his name to some European ancient cities: Julia Augusta Taurinorum, Augusta Treverorum, Augusta Protoria Salassorum etc.

But Augusta in Sicily was founded by Frederick II of Swabia in 1232 .

The names of the streets and squares affect by a lower vitality, except in the cases of great characters. In addition the names of streets are determined by the municipal commission on place names, and the name of the city is fixed by central government.

\section{Concluding Remarks}

From this presentation very fast, which has collected examples from space and time, we can infer that the names of the city are imposed by the various powers:

(1) the political and economic power, which gives the names of heads of state. The explorers are always a derivation of this power, because they were sent by the powerful to discover new lands and with the money of it. When Tsar Alexander I sent Bellingshausen to the southern lands thought he could take possession of the lands discovered;

(2) the power of the church, which imposed the names of the saints; but also Islamabad, the capital of Pakistan, can be included in this religious power;

(3) the power of the military commanders, who impose to cities names of battles won and lost. Mussolini was forced by military commanders to give the names of the battles of World War II to the villages founded in the Pontine Plain. At first he was not convinced. 